\title{
Dynamic Mechanical Properties of Hybrid Layered Silicates/Kaolin Geopolymer Filler in Epoxy Composites
}

\author{
YUSRINA MAT DAUD1*, KAMARUDIN HUSSIN ${ }^{2,3}$, AZLIN FAZLINA OSMAN ${ }^{1,2}$, CHE MOHD RUZAIDI GHAZALI ${ }^{4}$, \\ MOHD MUSTAFA AL BAKRI ABDULLAH ${ }^{2,3}$, ANDREI VICTOR SANDU $3,5 *$ \\ ${ }^{1}$ School of Materials Engineering, Universiti Malaysia Perlis, 02600 Jejawi, Perlis, Malaysia \\ ${ }^{2}$ Fakulti Teknologi Kejuruteraan, Universiti Malaysia Perlis (UniMAP), Kangar, Perlis, Malaysia \\ ${ }^{3}$ Center of Excellence Geopolymer \& Green Technology (CEGeoGTech), Universiti Malaysia Perlis (UniMAP), Kangar, Perlis, \\ Malaysia \\ ${ }^{4}$ School of Fundametal Science, Universiti Malaysia Terengganu (UMT), Kuala Terengganu, Terengganu, Malaysia \\ ${ }^{5}$ Gheorghe Asachi Technical University of lasi, Faculty of Materials Science and Engineering, 41 D. Mangeron Blvd., 700050, Iasi, \\ Romania
}

Preparation epoxy based hybrid composites were involved kaolin geopolymer filler, organo-montmorillonite at 3phr by using high speed mechanical stirrer. A mechanical behaviour of neat epoxy, epoxy/organomontmorillonite and its hybrid composites containing 1-8phr kaolin geopolymer filler was studied upon cyclic deformation (three-point flexion mode) as the temperature is varies. The analysis was determined by dynamic mechanical analysis (DMA) at frequency of $1.0 \mathrm{~Hz}$. The results then expressed in storage modulus $\left(E^{\prime}\right)$, loss modulus $\left(E^{\prime \prime}\right)$ and damping factor (tan $\delta$ ) as function of temperature from $40^{\circ} \mathrm{C}$ to $130^{\circ} \mathrm{C}$. Overall results indicated that $E^{\prime}, E^{\prime \prime}$ and Tg increased considerably by incorporating optimum 1phr kaolin geopolymer in epoxy organo-montmorillonite hybrid composites.

Keywords: kaolin, epoxy, compressive, organo montmorillonite, composites,geopolymer filler

In the growth of nanotechnology research area, the incorporation of nanoparticles such as nanoclay was observed as an effective way to toughen epoxy resin. The researches on epoxy/ layered silicate nanocomposites are widely explored and commonly reported. However, the use of single filler has limitation in terms of assisting the matrix to achieve high mechanical performance when subjected to various mechanical loads [1-4]. The enhancement in mechanical properties was sometimes accompanied by reduction in thermal properties [5]. Therefore, researchers have started to employ hybrid fillers in order to obtain composite materials with greater combination properties. Hybrid composite is another method allowing a third phase materials integrate into composites system whereby the incorporation of two reinforcement material into epoxy resin significantly demonstrated beneficial improvement in mechanical properties compared to single filler [6].

Epoxy based hybrid composites having layered silicates (clay) as filler have been extensively studied in recent years involving the use of co-filler such silica nano particle $[7,8]$ carbon fiber [9] and glass fiber [10]. However, it is limited for epoxy hybrid composites especially for hybrid filler using layered silicates and geopolymer filler has not been addressed so far. Geopolymer is inexpensive and ecofriendly materials obtained through synthetic procedures with natural silica-aluminates source and it is very well known in civil engineering field for construction purposes and other engineering application. These materials show excellent mechanical properties, low shrinkage, thermal stability, freeze-thaw, acid and fire resistance, long term durability and recyclability so the application of geopolymer based materials covering many fields [11-20].

Dynamic mechanical analysis is a sensitive and effective thermomechanical technique to determine the viscoelastic properties of polymer composite materials [21]. The resulted dynamic mechanical analysis expressed in storage modulus ( $\left.E^{\prime}\right)$, loss modulus ( $\left.E^{\prime \prime}\right)$ and damping factor $(\tan \delta)$. The storage modulus $\left(E^{\prime}\right)$ that related with Young's modulus is to determines the stiffness and load bearing capability of the composite materials. Meanwhile, loss modulus ( $\left.E^{\prime \prime}\right)$ defines a viscous response of the materials [22]. The temperature range of changes in thermosetting polymer from a glassy, hard or rigid state to a more pliable, compliantor rubbery state can be observed by glass transition temperature $(\mathrm{Tg})$. It has been reviewed that hybrid composites displayed the increase $\mathrm{Tg}$ in comparison with the control epoxy [23]. In addition, the incorporation of hybrid filler in epoxy matrices also has reported increased the storage and loss modulus [21]. Thefore this study was embarked to analyze the effect thermomechanical properties of kaolin geopolymer filler at different loading in epoxy organo-montmorillonite hybrid composites.

\section{Experimental part \\ Materials}

The organo-montmorillonite (organo-MMT) used was surface modified contains $35-45 w t \%$ of dimethyldialkyl (C14-C18) amine were sourced from Zarm Scientific \& Supplies Sdn. Bhd. Meanwhile, epoxy diglycidyl ether of bisphenol A (DGEBA) was provided by Euro Pharma (M) Sdn Bhd. The curing agent, isophorondiamine (IPDA) were sourced from Dr. Rahmatullah Holding Sdn. Bhd. Kaolin raw materials was sourced from Arab Saudi.

\section{Sample preparation}

Organo-MMT were dried in a vacuum oven for 12 hours at $60^{\circ}$ prior to mixing. The mixing of epoxy (DGEBA) based hybrid with organo-montmorillonite at 3phr and kaolin geopolymer filler at different content 1, 3,5 and 8phr was carried out by using mechanical mixing within $3 \mathrm{~h}$. The mixture was cured with cycloaliphatic amine curing agent IPDA in stoichiometric amount per hundred parts of epoxy

* email: yusrina@unimap.edu.my; sav@tuiasi.ro 
resin and degassed in vacuum chamber to remove entrapped air afterward cured at room temperature.

\section{Testing and Characterization}

Dynamic mechanical characterization studies were performed by Dynamic mechanical analysis (DMA) using Pyris Diamond DMA model, USA. Analysis was executed on the three point bending mode using dual cantilever system. The dynamic measurement is based on sinusoidal oscillation mode. The tested specimen were prepared in the form rectangular with dimension of 50x $10 \times 1 \mathrm{~mm}$. The tested specimen were run as a function of temperature from $30-450^{\circ} \mathrm{C}$ at frequency $1 \mathrm{~Hz}$ in flowing purified nitrogen gas.

\section{Results and discussions}

The dynamic mechanical analysis (DMA) was performed to study the influence of kaolin geopolymer filler loading in epoxy organo-montmorillonite composites through thermomechanical properties. A mechanical behaviour of epoxy organo-MMT and the hybrid composite with kaolin geo-filler (K-g) containing 1-8phrgeo-fillers has been studied in cyclic deformation conditions (three-point flexion mode) as a function of temperature at frequency of $1.0 \mathrm{~Hz}$.

Figure 1 show the storage modulus ( $E^{\prime}$ ) of epoxy organomontmorillonite (E/OMMT) and hybrid composite with kaolin geopolymer filler (E/OMMT/K-g). As can be seen from the figure, storage moduus, $E^{\prime}$ of hybrid composites increased at all temperatures. This situation explained the maximum energy stored in materials during cyclical deformation has greater than E/OMMT. Details storage modulus was summarized in table 1 . It is clear that incorporation of geopolymer fillers into epoxy organo-MMT has enhanced by $25 \%$ the storage modulus ( $\left.E^{\prime}\right)$ than $E /$ OMMT. The introduction of optimum 1 phr geo-fillers for K$\mathrm{g}$ has caused remarkable increase $3.357 \mathrm{GPa}$ in storage modulus compared to epoxy organo-MMT 2.687GPa and neat epoxy 2.348GPa.

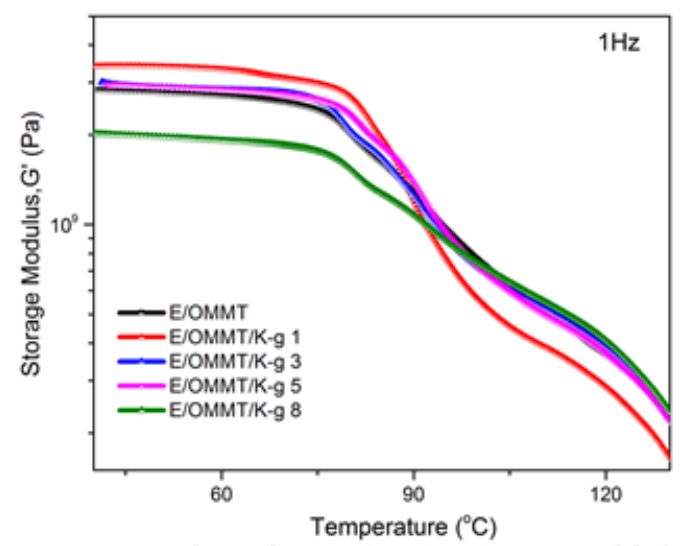

Fig. 1. Temperature dependence of E', for E/OMMT and hybrid composite with kaolin geopolymer fillers $(\mathrm{K}-\mathrm{g})$

Table 1

STORAGE MODULUS, E' OF EPOXY/ORGANO-MMT AND HYBRID COMPOSITE WITH KAOLIN (K-G) GEOPOLYMER FILLERS

\begin{tabular}{|cc|}
\hline Sampels & Storage Modulus, E' (GPa) \\
\hline Epoxy & 2.348 \\
$\mathrm{E} / \mathrm{OMMT}$ & 2.687 \\
\hline $\mathrm{E} / \mathrm{MMT} / \mathrm{K} 1$ & \\
$\mathrm{E} / \mathrm{MMT} / \mathrm{K} 3$ & 3.357 \\
$\mathrm{E} / \mathrm{MMT} / \mathrm{K} 5$ & 2.799 \\
$\mathrm{E} / \mathrm{MMT} / \mathrm{K} 8$ & 2.743 \\
\end{tabular}

Such improvement is caused by the uniformity dispersed of organo-MMT and geo-fillers and enhanced interfacial adhesion for load transfer from epoxy matrix to organoMMT and geo-fillers [24]. However, as the temperature increase, all the epoxy-organo MMT contain with 2-8phr kaolin geo-fillers show gradual drop in storage modulus up to $1.881 \mathrm{Gpa}$.

\section{Loss Modulus, E"}

Loss modulus ( $\left.E^{\prime \prime}\right)$ is proportional to the amount energy that dissipated as heat and it has been measured by viscous response of the materials under stress condition [22]. The $E^{\prime \prime}$ temperature for epoxy organo-montmorillonite (E/ OMMT) and hybrid composite with kaolin geopolymer filler (E/OMMT/K-g) at 1-8phr loading is presented in figure 2. From the figure 2, loss modulus has step up at temperature above $80^{\circ} \mathrm{C}$, and reverse trend was observed beyond $90^{\circ} \mathrm{C}$. The E" values has slightly increased at optimum 1phr K-g by $88.41 \mathrm{GPa}$ as compared to E/OMMT $88.28 \mathrm{GPa}$. However, a decreasing trend has been observed for hybrid composites contain 2-8phr K-g. This reduction in has been observed less abrupt at higher filler loadings due to poor particle distribution [25].

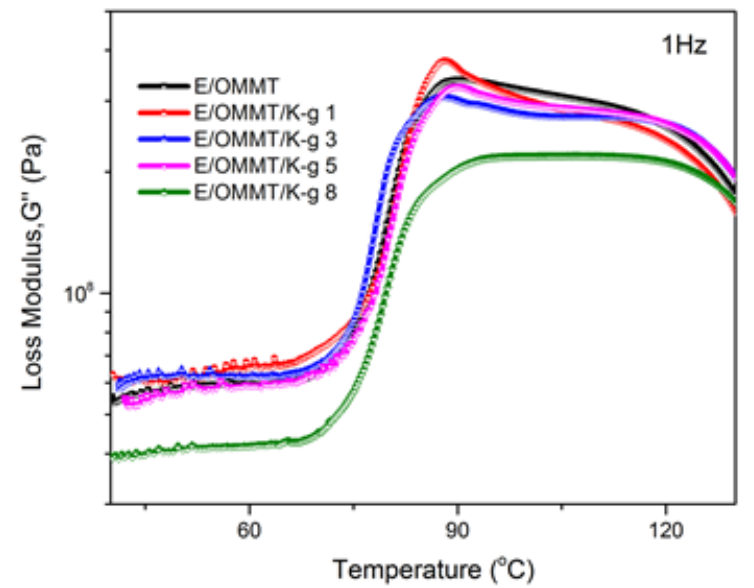

Fig. 2. Temperature dependence of $E^{\prime \prime}$, for E/OMMT and hybrid composite with kaolin geopolymer fillers (K-g)

\section{Glass Transition Temperature $(\mathrm{Tg})$}

The identification of $T$ in this study was preferably using Babayevsky et al. (1973) terminology and has been used by many authors in their study [1, 27-29]. Table 2 summarizes the estimated glass transition temperature $\left(T_{\text {}}\right)$ values obtained from the maximum damping peak temperature ( $\tan$ ä $\max$ ) from figure 3. The glass transition,

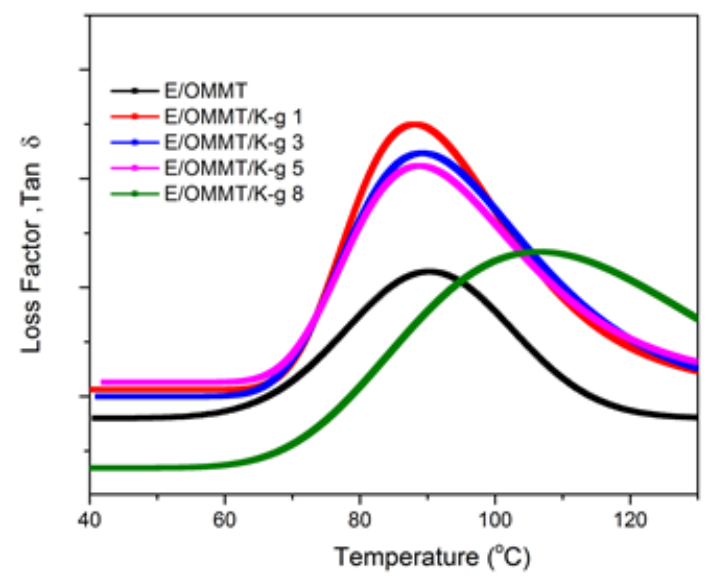

Fig. 3. Temperature dependence of $E^{\prime \prime}$, for E/OMMT and hybrid composite with kaolin geopolymer fillers (K-g) 
Table 2

GLASS TRANSITION TEMPERATURE OF EPOXY/ORGANO-MMT AND HYBRID COMPOSITE WITH KAOLIN (K-G) GEOPOLYMER FILLERS.

\begin{tabular}{|cc|}
\hline Sampels & $\mathrm{Tg}^{\mathrm{b}}\left({ }^{\circ} \mathrm{C}\right)$ \\
\hline Epoxy & 87.81 \\
E/OMMT & 89.68 \\
\hline $\mathrm{E} / \mathrm{MMT} / \mathrm{K} 1$ & 89.90 \\
$\mathrm{E} / \mathrm{MMT} / \mathrm{K} 3$ & 88.62 \\
$\mathrm{E} / \mathrm{MMT} / \mathrm{K} 5$ & 88.08 \\
$\mathrm{E} / \mathrm{MMT} / \mathrm{K} 8$ & 85.7 \\
\hline
\end{tabular}

$T_{\text {}}$ has given slightly increased in concurrence with storage modulus improvement for K-g $\left(89.90^{\circ}\right)$ at lphr filler loading.

The increasing of $T$ in concurrence with storage modulus improvement can be interpreted by addition of kaolin geopolymer fillers to epoxy organo-MMT can decrease the free space between the macromelocules resulting a decrease in rotation or movement in the hybrid composites an increased the $\mathrm{T}$ such discussed by Jin $\&$ Park (2012) in his study of epoxy resin/filler hybrid composites.

Overall, the $T_{\text {g }}$ value is by addition of geo-fillers are not instigating the glass transition temperature to higher degree. It is expected due the larger particles diameter of geopolymer fillers that cause the adhesion forces between the organo-MMT(nanofillers) and geopolymer fillers (microparticles) with the epoxy matrix are directly proportional to the specific surface area [30]. However, since the increasing of $T$ is related to decreased mobility chain of the matrix and for these hybrid composites, a better mechanical properties are expected as a results of the Van der Waals forces between epoxy matrix and fillers [30].

\section{Conclusions}

This research studies were emphasized the using of kaolin geopolymer at 1-8phr loading as co-filler in epoxy organo-montmorillonite composites. Epoxy based on diglycidyl ether of bisphenol A (DGEBA) was used as polymer matrices with incorporation isophorondiamine as the curing agent. The rectangular specimen was assessed under dynamic mechanical analysis to study the storage modulus ( $\left.E^{\prime}\right)$, loss modulus ( $E^{\prime \prime}$ ) and damping factor (tan $\delta)$ of hybrid composites. In general, the storage modulus $\left(E^{\prime}\right)$, loss modulus ( $\left.E^{\prime \prime}\right)$ and damping factor $(\tan \delta)$ were found increase at optimum 1phr kaolin geopolymer filler than origin epoxy and epoxy organo-montmorillonite composite.

Acknowledgment: The authors greatly acknowledgements Center of Excellence Geopolymer \& Green Technology (CEGeoGTech) and School of Material Engineering, Universiti Malaysia Perlis (UniMAP) and King Abdulaziz City for Science and Technology (KACST) and all the people who helped to ensure that the successful completion of this study.

\section{References}

1.MIYAGAWA H., JUREK R. . ., MOHANTY A. K., MISRA M., DRZAL L. T., Compos. Part A Appl. Sci. Manuf., 37, 2006, p. 54.
2.QI B., ZHANG Q.X., BANNISTER M., MAI Y. W., Compos. Struct., 75, 2006, p. 514.

3.JUMAHAT A., SOUTIS C., ABDULLAH S. A., KASOLANG S., Procedia Eng., 41, 2012, p. 1634

4.JUMAHAT A., SOUTIS C., MAHMUD J ., AHMAD N., Procedia Eng., 41, 2012, p. 1607.

5.LI X., ZHAN Z. J., PENG G. R., WANG W. K., Appl. Clay Sci., 55, 2012, p. 168.

6.WANG Y., ZHANG B., J. YE, Mater. Sci. Eng. A., 528, 2011, p. 7999.

7.YANG Y., LU C., SU X., J. Mater. Sci., 42, 2007, p. 6347.

8.ZENG Y., LIU H., MAI Y., DU X., Compos. Part B., 43, 2012, p. 90.

9.XU Y., VAN HOA S., Compos. Sci. Technol., 68, 2008, p. 854.

10.KISHORE A. N., MALHOTRA S. K., PRASAD N. S., Compos. Struct., 91, 2009, p. 266.

11.FERONE C., ROVIELLO G., COLANGELO F., CIOFFI R., TARALLO O., Appl. Clay Sci., 73, 2013, p. 42.

12.ABDULLAH, M.M.A., TAHIR, M.F.M., HUSSIN, K., BINHUSSAIN, M., SANDU, I.G., YAHYA, Z., SANDU, A.V., Rev. Chim. (Bucharest), 66, no. 7, 2015, p. 1001.

13.IBRAHIM, W.M.W., ABDULLAH, M.M.A., SANDU, A.V., HUSSIN, K., SANDU, I.G., ISMAIL, K.N., RADIR, A.A., BINHUSSAIN, M., Rev. Chim. (Bucharest), 65, no.11, 2014, p. 1340.

14.AL BAKRI, A.M.M., KAMARUDIN, H., NIZAR, I.K., SANDU, A.V., BINHUSSAIN, M., ZARINA, Y., RAFIZA, A.R., Rev. Chim. (Bucharest) 64, no. 4, 2013, p. 382.

15.ABDULLAH, M.M.A., NORDIN, N., TAHIR, M.F.M., KADIR, A.A., SANDU, A.V., International J ournal Of Conservation Science, 7, no. 3, 2016, p. 753.

16.AHMAD, R., ABDULLAH, M.M.A.B., HUSSIN, K., SANDU, A.V., BINHUSSAIN, M., JAYA, N.A., Reviews on Advanced Materials Science, 44, no. 1, 2016, p. 26.

17.RAMASAMY, S., HUSSIN, K., ABDULLAH, M.M.A.B., GHAZALI, C.M.R., SANDU, A.V., BINHUSSAIN, M., SHAHEDAN, N.F., Reviews on Advanced Materials Science, 42, no. 1, 2015, p. 83.

18.SHAHEDAN, N.F., ABDULLAH, M.M.A., HUSSIN, K., SANDU, I., GHAZALI, C.M.R., BINHUSSAIN, M., YAHYA, Z., SANDU, A.V., Mat. Plast., 51, no. 3, 2014, p. 258.

19.FARIS, M.A., ABDULLAH, M.M.A., SANDU, A.V., ISMAIL, K.N., MOGA, L.M., NECULAI, O., MUNIANDY, R., Mat. Plast., 54, no. 1, 2017, p. 145. 20.JAFFAR, M.I., BADARUZZAMAN, W.H.W., ABDULLAH, M.M.A., BAHAROM, S., MOGA, L.M., SANDU, A.V., Mat. Plast., 52, no. 2, 2015, p. 243.

21.SABA N., PARIDAH M. T., ABDAN K., IBRAHIM N. A., Mater. Chem. Phys., 184, 2016, p. 64.

22.SHINOJ S., VISVANATHAN R., PANIGRAHI S., VARADHARAJU N., Biosyst. Eng., 109, 2011, p. 99.

23.LIU H., ZHENG S., NIE K., Macromolecules., 38, 2005, p. 5088.

24.C CHEN., WANG H., XUE Y., XUE Z., LIU H., XIE X., MAI Y.W., Compos. Sci. Technol., 128, 2016, p. 207.

25.SCHLEMMER D., ANGELICA R. S., SALES M. J. A, Compos. Struct., 92, 2010, p. 2066

26.P BABAYEVSKY. G., GILLHAM J. K., J. Appl. Polym. Sci., 17, 1973, p. 2067.

27.LI G., LEE-SULLIVAN P., THRING R. W., J. THERM. ANAL. Calorim., 60,2000, p. 377.

28.PETERSSON L., OKSMAN K., Compos. Sci. Technol., 66, 2006, p. 2187.

29.J IN F.-L., PARK S.-J., Polym. Degrad. Stab., 97, 2012, p. 2148.

30.DE SOUZA J. P. B., DOS REIS J. M. L., Nanomater. Nanotechnol., 5, 2015, p. 1.

Manuscript received: 2.03 .2017 